\title{
Paullinia cupana (Guarana) for Chemotherapy-Induced Fatigue in Patients with Solid Tumors: A Meta-Analysis
}

\author{
Paullinia cupana (Guaraná) para fadiga induzida por quimioterapia em pacientes com tumores \\ sólidos: uma meta-análise \\ Cicilia Marques Rodrigues ${ }^{1}$ and Auro del Giglio ${ }^{1,2}$
}

How to cite: Rodrigues CM, Giglio A. Paullinia cupana (Guarana) for Chemotherapy-Induced
Fatigue in Patients with Solid Tumors: A Meta-Analysis. Clin Onc Let. 2018;3(1-2):53-61.
https://doi.org/10.4322/col.2018.007

\section{RESUMO}

Objetivo: Revisar a literatura sistematicamente para resumir todos os dados existentes recuperáveis sobre os efeitos anti-fadiga de Paullinia cupana em pacientes tratados com quimioterapia. Métodos: Entre setembro de 2017 e dezembro de 2017, procuramos, nas bases de dados PUBMED, MEDLINE e Cochrane Library. por publicações em inglês de adultos humanos (19 anos ou mais) de pacientes com tumores sólidos submetidos a quimioterapia que receberam Paullinia cupana versus placebo para fadiga. Empregamos os seguintes descritores MeSH (Medical Subject Headings): fadiga, guaraná (Paullinia) e quimioterapia. Também pesquisamos a bibliografia dos artigos selecionados. Resultados: Foram incluídos três ensaios clínicos randomizados envolvendo 134 pacientes. Apesar da heterogeneidade significativa, em comparação com o placebo, Paullinia cupana produziu melhorias estatisticamente significativas na fadiga medida pelos questionários Chalder ( $p<0,00001)$, Facit $\mathrm{F}(p=0,0004)$ e BFI $(p=0,004)$. Não houve toxicidade importante relacionada ao uso de guaraná. Conclusão: Concluímos que a Paullinia cupana é ativa para a fadiga induzida pela quimioterapia em pacientes com tumores sólidos.

Palavras-chave: Paullinia cupana; guaraná; fadiga; quimioterapia

\begin{abstract}
Objective: To review the literature systematically to summarize all retrievable existent data on the anti-fatigue effects of Paullinia cupana in chemotherapy-treated patients. Methods: Between September 2017 and December 2017 in the PUBMED, MEDLINE and Cochrane Library databases for publications in English of adult human studies (19 years or older) of patients with solid tumors undergoing chemotherapy who received Paullinia cupana versus placebo for fatigue. We employed the following MeSH (Medical Subject Headings) descriptors: fatigue, guarana (Paullinia) and chemotherapy. We also searched the bibliography of the selected articles. Results: We included three randomized clinical trials involving 134 patients. Despite significant heterogeneity, as compared with placebo, Paullinia cupana produced statistically significant improvements in fatigue measured by the Chalder $(p<0.00001)$, Facit F $(p=0.0004)$ and BFI $(p=0.004)$ questionnaires. There was no important toxicity related to the Guarana use. Conclusion: We conclude that Paullinia cupana is active for fatigue induced by chemotherapy in patients with solid tumors.
\end{abstract}

Keywords: Paullinia cupana; guarana; fatigue; chemotherapy

\section{INTRODUCTION}

Cancer-related fatigue (CRF) is defined as a persistent, subjective sense of physical or emotional tiredness, or mental exhaustion, related to cancer or to its treatment that is not proportional to the activities performed by the patient and can interfere with his/her functional capacity. ${ }^{1,2}$ Approximately $50 \%$ to $90 \%$ of cancer patients experience fatigue in general, with the latter figure representing patients undergoing anti-cancer treatments such as 
chemotherapy (CT) and radiotherapy (RT). Fatigue can persist for months to years in this population after $\mathrm{CT} .^{3,4}$ This symptom is a reliable and independent predictor of the decrease in a patient's satisfaction and quality of life. ${ }^{5}$

CRF has multifactorial pathogenesis. Among the described mechanisms are the effects of cancer and its treatment on the central nervous system, changes in energetic muscle metabolism, in sleep, increasing inflammatory activity and hormonal changes related to the effects on the hypothalamic-pituitary axis and menopause or androgen deprivation in men. ${ }^{6}$

Most patients with fatigue benefit from non-pharmacological treatment such as cognitive-behavioral therapy, exercise, hypnosis, relaxation and psychoeducation. ${ }^{1,2,7}$ Patients with moderate to severe CRF benefit from pharmacological treatment in combination with non-pharmacological treatment. ${ }^{8}$ Several small studies have suggested that methylphenidate improves this condition. ${ }^{9}$ Recently, however, negative results were obtained in a randomized trial. ${ }^{10}$ Yennurajalingam et al. ${ }^{11}$ reported a randomized study with dexamethasone showing positive effects of a short 14-day course of twice a day $4 \mathrm{mg}$ dose of dexamethasone over placebo.

The toxicity of stimulating medications such as methylphenidate and corticoids prompts a continuous search for pharmacological alternatives to treat CRF. Paullinia cupana (Guarana) is a plant native to the Amazon basin grown in Brazil and Venezuela whose tonic properties were already known by native Brazilian populations. We performed a double-blind, randomized crossover trial $^{2}$ with dry Paullinia cupana extract administered twice a day at a dose of $50 \mathrm{mg}$ in breast cancer patients receiving CT diagnosed with fatigue according to the Brief Fatigue Inventory (BFI). ${ }^{12}$ In this study, we observed significant benefits in patients treated with Paullinia cupana as compared with placebo. We aimed in this paper to review the literature systematically to summarize all retrievable existent data on the antifatigue effects of Paullinia cupana in chemotherapy-treated patients.

\section{METHODS}

\section{DATA SEARCH AND STUDY SELECTION}

We conducted a systematic search between September 2017 and December 2017 in the PUBMED, MEDLINE and Cochrane Library databases for publications in English of adult human studies (19 years or older) with the following MeSH (Medical Subject Headings) descriptors: fatigue, guarana (Paullinia) and chemotherapy. We also searched the bibliography of the selected articles.

Inclusion criteria were randomized clinical trials whose intervention was the administration of Paullinia cupana versus placebo in patients undergoing chemotherapy in which analysis of fatigue reduction was a primary outcome.

We excluded studies whose participants had hematological malignancies or who were receiving radiotherapy, whether exclusive or combined treatment (chemoradiotherapy), as well as publications such as abstracts, reviews, and preclinical studies.

We assessed the primary endpoint (fatigue intensity) from the published data. In the selected papers employed specific fatigue questionnaires such as the Brief Fatigue Inventory (BFI), ${ }^{13}$ Functional Assessment of Chronic Illness Therapy-Fatigue (FACIT-F) ${ }^{14}$ and Chalder Fatigue Scale. ${ }^{15}$

The $\mathrm{BFI}$ questionnaire consists of 10 questions, the first one to track fatigue in the last week, and the others divided into four groups on fatigue intensity during the previous 24 hours and its impact on usual activities, mood, mobility, work, interpersonal relationship and satisfaction with life. Each question is graded 0-10, with the higher scores representing worse fatigue.

The FACIT-F scale is a questionnaire with 40 questions about fatigue in the last seven days, divided into five categories, namely: physical well-being; social / family; emotional; functional; and additional considerations. Each question was scored from 0 to 4, so that, after performing the appropriate calculations (maximum of 160 points), the higher the score, the better the quality of life evaluation. ${ }^{14}$

The scale also referred to as CFQ - 11 (Chalder Fatigue Questionnaire), elaborates 11 questions about the presence of fatigue in the last 30 days, being able to be graded 0-3 with a maximum score of 33 . Higher scores correlate with worse fatigue severity. ${ }^{15}$ 


\section{EXTRACTION OF DATA AND QUALITY EVALUATION STATISTICAL ANALYSIS}

The overall effects of each trial represent the aggregate of all patients treated with Paullinia cupana compared with those receiving placebo. We analyzed fatigue as a non-dichotomous (continuous) outcome. We employed fixed effect analysis model, and as effect measure, we obtained the mean difference between the intervention group (Paullinia cupana) and the control group (placebo). We chose to use the 95\% confidence intervals around the differences and plotted the results using forest plots.

We evaluated the assumption of homogeneity by the $\chi 2$ test with degrees of freedom equal to the number of studies analyzed minus 1. For all the meta-analysis calculations and graphs we used Review Manager Software version 5.3. ${ }^{16}$

\section{RISK ASSESSMENT OF BIAS IN INCLUDED STUDIES}

We followed the guidance provided by the Cochrane Handbook for Systematic Reviews of Interventions ${ }^{17}$ to assess the risk of bias in the included studies regarding generation of the lease sequence, blinding of participants, investigators, and outcome assessors; and incomplete outcome data.

\section{RESULTS}

\section{BIBLIOGRAPHIC SEARCH}

The initial screening process to find the eligible studies consisted in a search for randomized clinical trials using the chosen MeSH terms in the PUBMED and Cochrane Library database. We found 63 articles (figure 1).

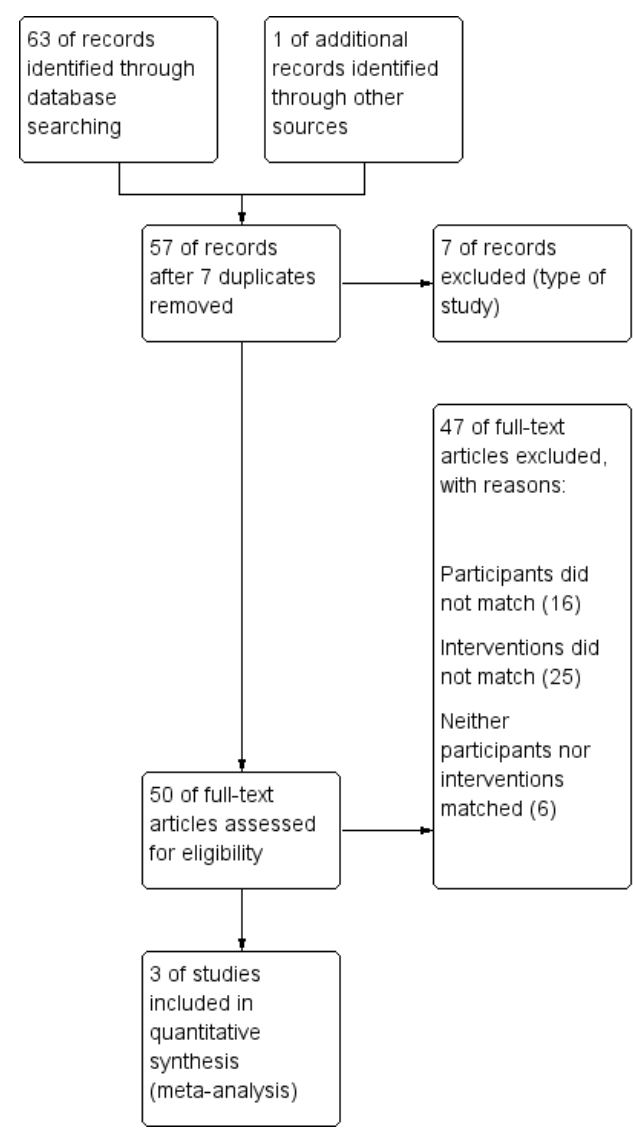

Figure 1. Flowchart of selection of studies included in meta-analysis. 
We added one paper found from another source ${ }^{18}$ accessed from a Brazilian journal which was previously published by one of the authors of this meta-analysis. We excluded seven publications because four of them were reviews; ${ }^{1,3,19,20}$ two were observational studies ${ }^{21,22}$ and 1 was a preclinical study. ${ }^{23}$ Finally, we included three randomized clinical trials ${ }^{2,18,24}$ involving 134 patients in this meta-analysis.

\section{CHARACTERISTICS OF THE STUDIES}

The characteristics of the studies are shown in Table 1. The selected studies were published in 2008, 2011 and 2013, conducted in Brazil by the same group of researchers. The sample ranged from 26 to 75 participants, with a total of 134 patients. The article (Campos et al., 2011) $)^{2}$ considered only female patients with breast cancer. The remaining studies also included patients with other solid tumors.

Table 1. Characteristics of the studies and participants

\begin{tabular}{|c|c|c|c|c|c|c|c|c|c|c|c|}
\hline \multirow{3}{*}{$\begin{array}{c}\text { Name of the } \\
\text { trial }\end{array}$} & \multirow{3}{*}{ Experimental } & \multirow{3}{*}{$\begin{array}{l}\text { Daily } \\
\text { dose }\end{array}$} & \multirow{3}{*}{$\begin{array}{c}\mathbf{N} \\
\text { arms }\end{array}$} & \multirow{3}{*}{ Comparer } & \multirow{3}{*}{$\begin{array}{l}\text { Time of } \\
\text { study }\end{array}$} & \multirow{3}{*}{$\begin{array}{c}\text { Total of } \\
\text { participants }\end{array}$} & \multirow{3}{*}{$\begin{array}{c}\text { Men/ } \\
\text { Women }\end{array}$} & Age (years) & Age (years) & \multirow{3}{*}{$\begin{array}{c}\text { Type of } \\
\text { tumor } \\
\text { (B/GI/L/HN/ } \\
\text { GU) }\end{array}$} & \multirow{3}{*}{$\begin{array}{l}\text { Clinical } \\
\text { Stage } \\
\text { (I/II/III/IV) }\end{array}$} \\
\hline & & & & & & & & (mean $\pm S D)$ & (mean \pm SD) & & \\
\hline & & & & & & & & Paullinia & Placebo & & \\
\hline $\begin{array}{l}\text { Miranda, et al., } \\
2008^{18}\end{array}$ & Paullinia & $75 \mathrm{mg}$ & 2 & Placebo & 42 days & $26^{a}$ & NR & $55.1 \pm 12.7$ & $57.2 \pm 8.52$ & NR & NR \\
\hline $\begin{array}{l}\text { Campos, et al., } \\
2011^{2}\end{array}$ & Paullinia & $100 \mathrm{mg}$ & 2 & Placebo & 49 days & $75^{b}$ & $0 / 75$ & $51.76 \pm 9.73$ & $50.2 \pm 11.95$ & 75/0/0/0/0 & (3/33/25/NR) \\
\hline $\begin{array}{l}\text { del Giglio, et al., } \\
2013^{24}\end{array}$ & Paullinia & $75 \mathrm{mg}$ & 2 & Placebo & 42 days & $33^{c}$ & $13 / 20$ & $58 \pm 8.09$ & $52.17 \pm 15.17$ & $10 / 11 / 3 / 3 / 2$ & NR \\
\hline
\end{tabular}

$\mathrm{N}=$ number; SD = Standart Deviation; NR = not reported; B - Breast; GI - Gastrintestinal; L - Lung; HN - Head and Neck; GU - Geniturinary; a - 26 participants randomized 13 in group A (placebo-guarana) and 13 in group B (guarana-placebo); b - 75 participants randomized 43 in group A (placebo-guarana) and 32 in group B (guarana-placebo). 15 participants were lost, after randomization: 8 in group A e 7 in group B; c - 40 participants were included during the induction phase (all of them received guarana). 4 participants were lost before and 3 after randomization. Thus, 17 patients in group A (placebo) and 16 patients in group B (placebo) were included.

\section{RISK OF BIAS AND DATA QUALITY}

Details of the risks of bias are presented in figures 2 and 3. One of the studies was assessed as being at high risk because it was not double-blinded and another as an uncertain risk since there was no description regarding the methodology used to allocate the participants (such as sealed and sequentially numbered envelopes).

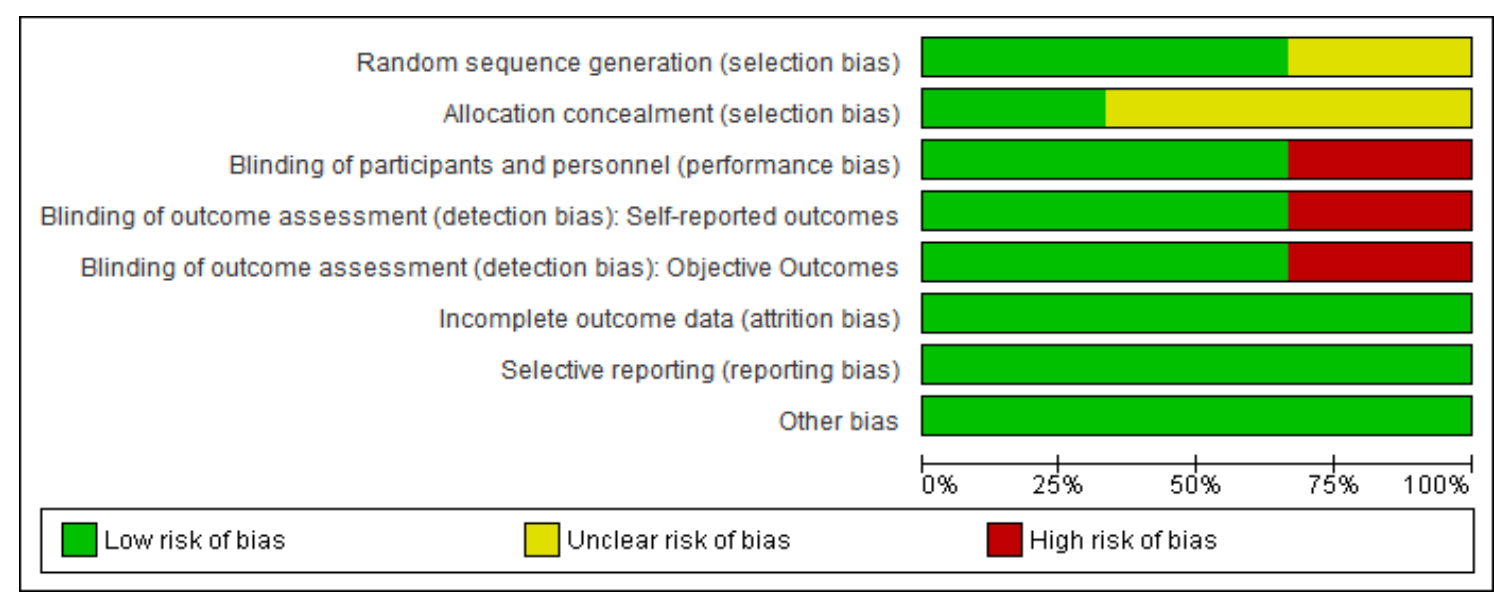

Figure 2. Overall risk of bias according to specific characteristics of the studies. 


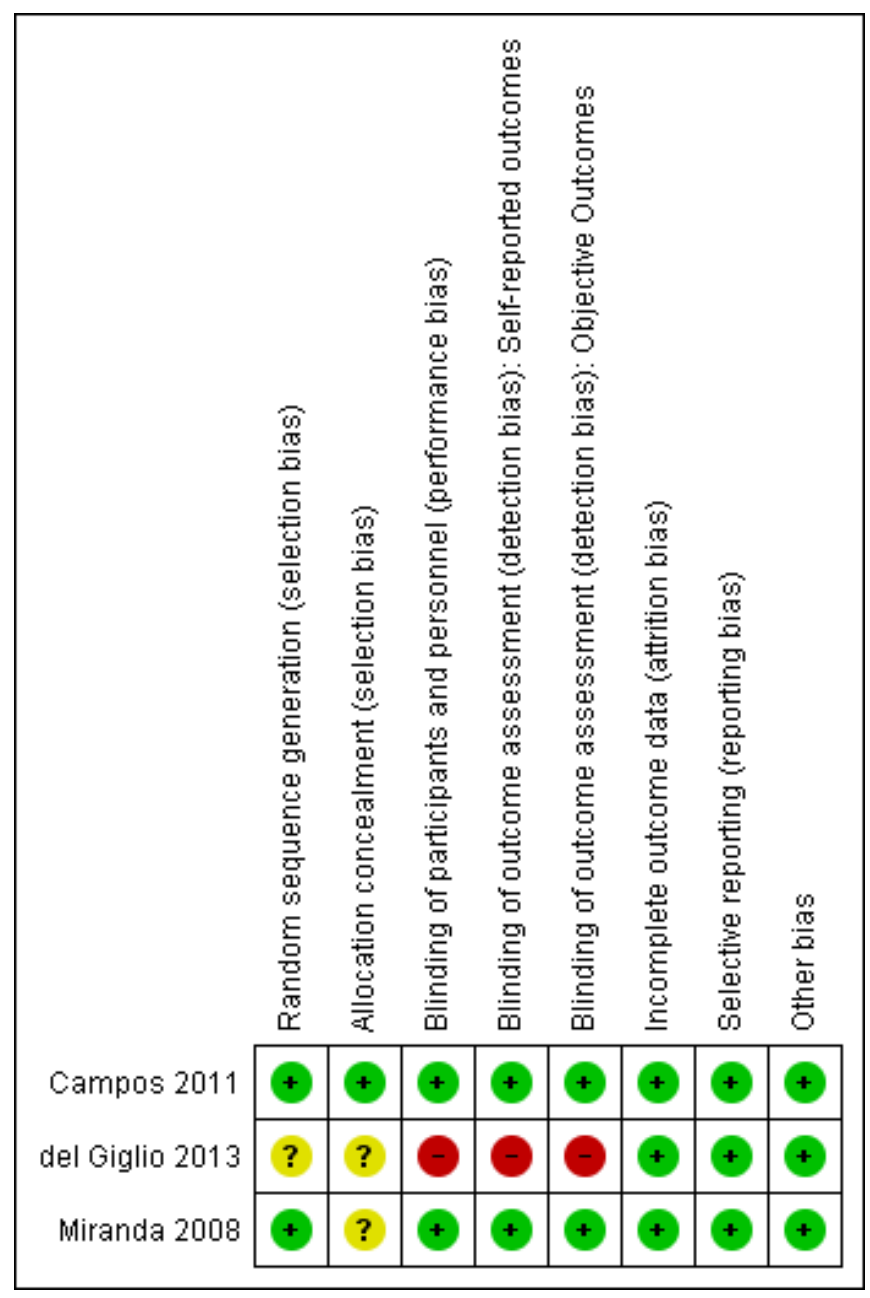

Figure 3. Quality assessment for the risk of bias for each study.

\section{ANALYSIS OF THE PRIMARY OUTCOME}

The analysis of the fatigue intensity after Paullinia cupana or placebo took into account three distinct scales which prompted us to elaborate of 3 different forest plots, one for each scale.

Figure 4 shows the forest plot from the fatigue analysis according to the BFI scale. All three studies were included in the analysis. There was significant heterogeneity between the studies (Heterogeneity: $\mathrm{Chi}^{2}=23.75, \mathrm{df}=2$ $\left.(P<0.00001), I^{2}=92 \%\right)$. Therefore, we conducted the sensitivity analysis to explore the potential sources of heterogeneity. We identified the study by Miranda et al., $2008^{18}$ as the possible main source of heterogeneity. When we excluded this study ${ }^{18}$ the heterogeneity was substantially reduced $\left(\mathrm{Chi}^{2}=6.78, \mathrm{df}=1(\mathrm{P}=0.009), \mathrm{I}^{2}=85 \%\right)$. In both instances, before and after the sensitivity analysis, the Paullinia cupana arm was superior.

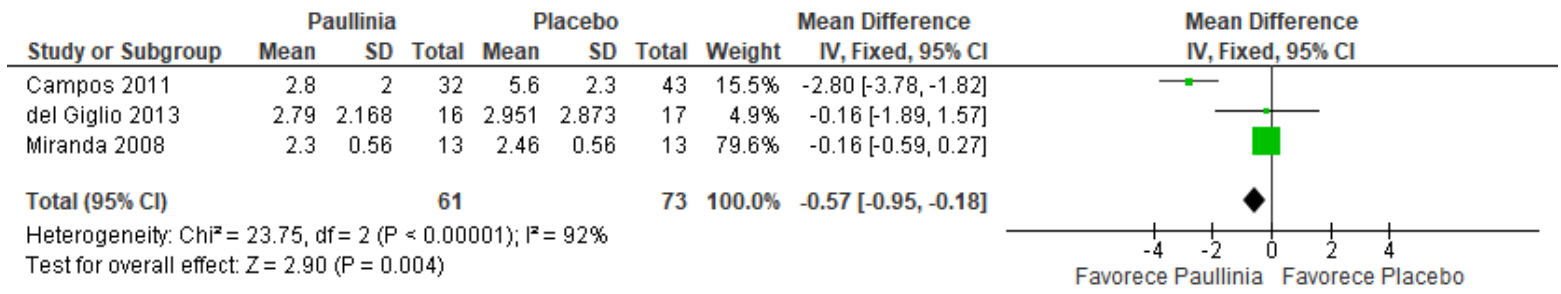

Figure 4. Forest plot from fatigue analysis according to BFI scale. 
The forest plot shown in figure 5 compares two studies by Campos et al., 2011 and del Giglio et al., 2013,2,24 excluding the one by Miranda et al, ${ }^{18}$ since this study did not employ the FACIT-F questionnaire. In this combined analysis, there was no statistically significant heterogeneity $\left(\mathrm{Chi}^{2}=1.72, \mathrm{df}=1(\mathrm{P}=0.19), \mathrm{I}^{2}=42 \%\right)$ and the result also favored the use of the Paullinia cupana arm.

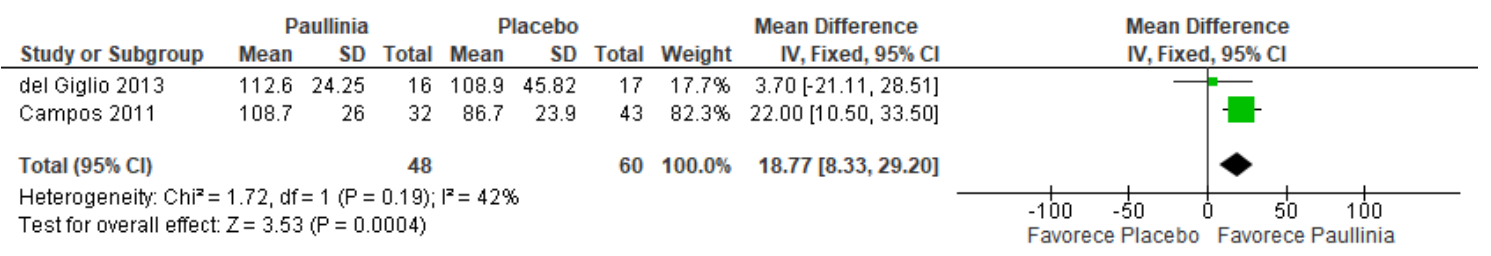

Figure 5. Forest plot comparing two studies according to FACIT-F questionnaire. FACIT-F = Functional Assessment of Chronic Illness Therapy-Fatigue The trial (Miranda, et al., 2008) did not analyze fatigue according to FACIT-F, reason that it was excluded from this analysis.

Figure 6 shows the forest plot for the analysis for Chalder Fatigue Scale results. There was also remarkable heterogeneity $\left(\mathrm{Chi}^{2}=22.36, \mathrm{df}=2(\mathrm{P}<0.0001), \mathrm{I}^{2}=91 \%\right)$ that justified the sensitivity analysis. Once again, the heterogeneity was reduced $\left(\mathrm{Chi}^{2}=0.17, \mathrm{df}=1(\mathrm{P}=0.68), \mathrm{I}^{2}=0 \%\right)$ when we excluded the study Miranda, et al. $2008 .{ }^{18}$

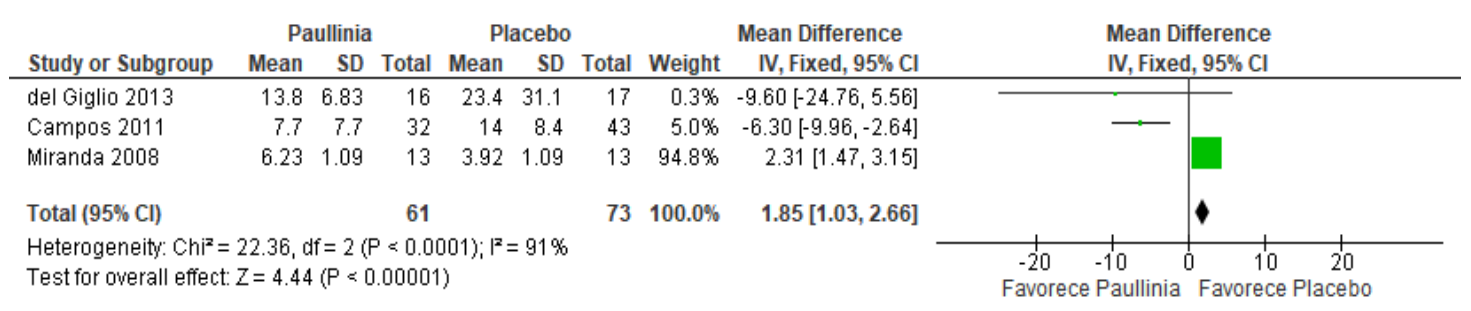

Figure 6. Forest plot for the analysis according to Chalder Fatigue Scale results.

The most common adverse events reported in these studies were insomnia, palpitation, nausea, anxiety and dry skin, however there was no statistical significance difference between placebo and experimental arm.

\section{DISCUSSION}

This meta-analysis of 3 randomized clinical trials, including 134 patients, evaluated the efficacy of Paullinia cupana in reducing the fatigue intensity in patients with solid tumors undergoing chemotherapy. The result of this meta-analysis suggests that guarana significantly reduces cancer-related fatigue in this scenario.

One of the studies ${ }^{18}$ rated as having a low risk of bias, probably increased the heterogeneity. In fact, when we excluded this trial during sensitivity analysis, the heterogeneity was substantially reduced. Nevertheless, the results favored the Paullinia cupana arm over placebo in all instances. Interestingly, in this study, ${ }^{18}$ Paullinia cupana had no benefit in decreasing fatigue in unselected chemotherapy-treated patients. In fact, this study ${ }^{18}$ also included patients with no fatigue at randomization. One of the possible reasons why there was no observed anti-fatigue effect of Paullinia cupana in this small study could be that unlike the other two included studies, the patients with no fatigue at randomization may have diluted the anti-fatigue effects of Paullinia cupana.

Paullinia cupana has a chemical composition characterized by alkaloids known as methylxanthines, which includes caffeine, theophylline, and theobromine, terpenes, flavonoids and amides. ${ }^{25}$ Xanthines have stimulating effects on the central nervous system; of them, caffeine has the most potent action. The physiological activity of guarana has been the object of debate and is most likely related to a complex of caffeine with tannins at a molecular level. ${ }^{26}$ In turn, most of the therapeutic properties of guarana, such as its antioxidant capacity, are attributed to high concentrations of phenolic compounds (tannins, among others), whereas its anti-inflammatory role is ascribed to the presence of saponins. ${ }^{27}$ 
The mechanism of action of guarana in patients with CRF is unknown. Calixto et al. performed studies ${ }^{28}$ on $\mathrm{Balb} / \mathrm{c}$ mice to evaluate the possible anti-fatigue mechanism of action of guarana. The animals received an intraperitoneal injection of bacterial lipopolysaccharide (LPS), which is known to induce a state of lassitude that mimics a state of intense fatigue. Subsequently, the animals received dry guarana extract orally at doses of 30, 100 and $300 \mathrm{mg} / \mathrm{kg}$ or dexamethasone at a dose of $1 \mathrm{mg} / \mathrm{kg}$. At the end of the experiment, serum IL-1 levels were significantly reduced in animals treated with guarana, whereas IL-6 levels did not change. Interestingly, the increased expression of IL- 6 and tumor necrosis factor (TNF)- $\alpha$ mRNA in the brain, as measured by quantitative RT-PCR $2 \mathrm{~h}$ after LPS injection, was significantly suppressed in animals treated with Paullinia cupana extract. Subsequent data (Calixto et al., personal communication) showed that guarana extract significantly reduces the expression of cyclooxygenase 2 (COX2) and nuclear factor kappa-light-chain-enhancer of activated B cells (NF-KB) in brain tissue after intraperitoneal LPS injection. It is thus possible that these anti-inflammatory effects of guarana may explain at least in part its anti-fatigue effects.

Some studies have evaluated the properties of other herbal medications against cancer-related fatigue. In 2013, a non-randomized clinical trial studied the role of Withania somnifera ${ }^{29}$ in breast cancer patients undergoing chemotherapy; and those who used the plant in combination had more prominent reductions in fatigue associated with improved quality of life. A randomized, double-blind, multi-center trial with 364 patients showed the benefit of Panax quinquefolius (ginseng) in the control of fatigue, especially in patients undergoing chemotherapy. ${ }^{30}$ In 2014, a systematic review ${ }^{31}$ evaluated 10 randomized clinical trials with a total of 751 patients, who used Chinese medicinal herbs versus placebo in combination or not with chemotherapy or palliative care. In that study, the results of treatment with the herbs, alone or in combination with oncological treatment, showed benefit in reducing fatigue and improving quality of life.

There are some potential limitations in this meta-analysis that must be considered when interpreting the results. Our study included only three randomized clinical trials, with relatively small samples. Compared with bigger studies, small sample trials are more likely to overestimate the effects of treatment. Also, the included studies were not homogeneous regarding patient characteristics (tumor type, clinical staging, and guarana dose), which may increase heterogeneity and have a potential impact on results.

Therefore, although larger prospective, randomized and controlled studies are still needed to corroborate our findings, this meta-analysis offers preliminary evidence for the beneficial effects of Paullinia cupana in reducing chemotherapy-induced fatigue in patients with solid tumors undergoing chemotherapy.

\section{REFERENCES}

1. Campos MPO, Hassan BJ, Riechelmann R, Giglio A. Cancer-related fatigue: a review. Rev Assoc Med Bras. 2011;57(2):211-9. http://dx.doi.org/10.1590/S0104-42302011000200021. PMid:21537710.

2. Campos MPO, Riechelmann R, Martins LC, Hassan BJ, Casa FB, Del Giglio A. Guarana Paullinia cupana improves fatigue in Breast Cancer patients undergoing systemic chemotherapy. J Altern Complement Med. 2011;17(6):505-12. http://dx.doi.org/10.1089/acm.2010.0571. PMid:21612429.

3. Cella $D$, Viswanathan $H$, Hays $R$, et al. Development of a fatigue and functional impact scale in anemic cancer patients receiving chemotherapy. Cancer. 2008;113(6):1480-8. http://dx.doi.org/10.1002/cncr.23698. PMid:18642348.

4. Wang XS, Giralt SA, Mendoza TR, et al. Clinical factors associated with cancer-related fatigue in patients being treated for leukemia and non-Hodgkin's lymphoma. J Clin Oncol. 2002;20(5):1319-28. PMid:11870175.

5. Gupta D, Lis CG, Grutsch JF. The relationship between cancer-related fatigue and patient satisfaction with quality of life in cancer. J Pain Symptom Manage. 2007;34(1):40-7. http://dx.doi.org/10.1016/j.jpainsymman.2006.10.012.

PMid:17532179.

6. Ryan JL, Carroll JK, Ryan EP, Mustian KM, Fiscella K, Morrow GR. Mechanisms of cancer-related fatigue. Oncologist. 2007;12(Suppl 1):22-34. http://dx.doi.org/10.1634/theoncologist.12-S1-22. PMid:17573453. 
7. Lotfi-Jam K, Carey M, Jefford M, Schofield P, Charleson C, Aranda S. Nonpharmacologic strategies for managing common chemotherapy adverse effects: a systematic review. J Clin Oncol. 2008;26(34):5618-29.

http://dx.doi.org/10.1200/JCO.2007.15.9053. PMid:18981466.

8. Minton O, Richardson A, Sharpe M, Hotopf M, Stone P. A systematic review and meta-analysis of the pharmacological treatment of cancer-related fatigue. J Natl Cancer Inst. 2008;100(16):1155-66. http://dx.doi.org/10.1093/jnci/djn250. PMid:18695134.

9. Minton O, Richardson A, Sharpe M, Hotopf M, Stone P. Drug therapy for the management of cancer-related fatigue. Cochrane Database Syst Rev. 2010;(7):CD006704. PMid:20614448.

10. Bruera E, Yennurajalingam S, Palmer JL, et al. Methylphenidate and/or a nursing telephone intervention for fatigue in patients with advanced cancer: a randomized, placebo-controlled, phase II trial. J Clin Oncol. 2013;31(19):2421-7. http://dx.doi.org/10.1200/JCO.2012.45.3696. PMid:23690414.

11. Yennurajalingam S, Frisbee-Hume S, Palmer JL, et al. Reduction of cancer-related fatigue with dexamethasone: a double-blind, randomized, placebo-controlled trial in patients with advanced cancer. J Clin Oncol. 2013;31(25):3076-82. http://dx.doi.org/10.1200/JCO.2012.44.4661. PMid:23897970.

12. Mendoza TR, Wang XS, Cleeland CS, et al. The rapid assessment of fatigue severity in cancer patients: use of the Brief Fatigue Inventory. Cancer. 1999;85(5):1186-96. http://dx.doi.org/10.1002/(SICI)1097-0142(19990301)85:5<1186::AIDCNCR24>3.0.CO;2-N. PMid:10091805.

13. MdAnderson. The Brief Fatigue Inventory - BFI [Internet]. Houston: The University of Texas MD Anderson Cancer Center; 1997 [cited 2019. Apr, 03]. Available from: https://www.mdanderson.org/research/departments-labsinstitutes/departments-divisions/symptom-research/symptom-assessment-tools/brief-fatigue-inventory.html

14. FACIT. Questionnaires [Internet]. FACIT.org; 2010. [cited 2019. Apr, 03]. Available from: http://www.facit.org/FACITOrg/Questionnaires

15. Chalder T, Berelowitz G, Pawlikowska T, et al. Development of a tafigue scale. J Psychosom Res. 1993;37(2):147-53. http://dx.doi.org/10.1016/0022-3999(93)90081-P. PMid:8463991.

16. Cochrane. RevMan 5 [Internet]. London: Cochrane Community; 2014 [cited 2019. Apr, 03]. Available from: http://community.cochrane.org/tools/review-production-tools/revman-5/revman-5-download

17. Higgins J, Green S. Cochrane handbook of systematic reviws of interventions 5.2 [Internet]. London: Cochrane Library; 2017 [cited 2019. Apr, 03]. Available from: http://training.cochrane.org/handbook

18. Miranda VC, Trufelli DC, Fêde ÂB, et al. Guarana (Paullinia cupana) for chemotherapy-related fatigue. Einstein. 2008;6(2):195-9.

19. Sette CVM, Alcântara BBR, Schoueri JHM, et al. Purified dry Paullinia cupana (PC-18) extract for chemotherapyinduced fatigue: results of two double-blind randomized clinical trials. J Diet Suppl. 2018;15(5):673.

http://dx.doi.org/10.1080/19390211.2017.1384781. PMid:29190155.

20. McMillan R, Forssell H, Buchanan J, Glenny A, Weldon J, Zakrzewska J. Interventions for treating burning mouth syndrome. Cochrane Libr. 2016;11:CD002779. PMid:27855478.

21. Mel JR, Salar A, Rodríguez CA, et al. A prospective observational study of the effectiveness, safety, and effect on fatigue of darbepoetin alfa for the treatment of chemotherapy-induced anaemia. Cochrane Database Syst Rev. 2008;24(10):2931-42. http://dx.doi.org/10.1185/03007990802381323. PMid:18775103.

22. Berger AM, Lockhart K, Agrawal S. Variability of patterns of fatigue and quality of life over time based on different breast cancer adjuvant chemotherapy regimens. Oncol Nurs Forum. 2009;36(5):563-70.

http://dx.doi.org/10.1188/09.ONF.563-570. PMid:19726396.

23. Cavalcanti AL, Oliveira MC, Florentino V, Santos J, Vieira F, Cavalcanti C. Short communication: in vitro assessment of erosive potential of energy drinks. Eur Arch Paediatr Dent. 2010;11(5):253-5. http://dx.doi.org/10.1007/BF03262757. PMid:20932401. 
24. Giglio AB, Cubero DI, Lerner TG, et al. Purified dry extract of Paullinia cupana (guaraná) (PC-18) for chemotherapyrelated fatigue in patients with solid tumors: an early discontinuation study. J Diet Suppl. 2013;10(4):325-34. http://dx.doi.org/10.3109/19390211.2013.830676. PMid:24237188.

25. Angelo PC, Nunes-Silva CG, Brígido MM, et al. Guarana (Paullinia cupana var. sorbilis), an anciently consumed stimulant from the Amazon rain forest: the seeded-fruit transcriptome. Plant Cell Rep. 2008;27(1):117-24. http://dx.doi.org/10.1007/s00299-007-0456-y. PMid:17917729.

26. Edwards HGM, Farwell DW, Oliveira LFC, Alia J-M, Hyaric ML, Ameida MV. FT-Raman spectroscopic studies of guarana and some extracts. Anal Chim Acta. 2005;532(2):177-86. http://dx.doi.org/10.1016/j.aca.2004.10.055.

27. Yoshizawa S, Horiuchi T, Fujiki H, Yoshida T, Okuda T, Sugimura T. Antitumor promoting activity of (-)-epigallocatechin gallate, the main constituent of "Tannin" in green tea. Phytother Res. 1987;1(1):44-7.

http://dx.doi.org/10.1002/ptr.2650010110.

28. Marcon R, Del Giglio A, Pianowski LF, Calixto JB. An analysis of the role of paulinia cupana (Guaraná) in blood IL-1b and brain IL-6 levels as well as brain IL-6 and TNF-a mRNA expression in mice. J Clin Oncol. 2011;29(Suppl 15):e21002. http://dx.doi.org/10.1200/jco.2011.29.15_suppl.e21002.

29. Biswal BM, Sulaiman SA, Ismail HC, Zakaria H, Musa KI. Effect of Withania somnifera (Ashwagandha) on the development of chemotherapy-induced fatigue and quality of life in breast cancer patients. Integr Cancer Ther. 2013;12(4):312-22. http://dx.doi.org/10.1177/1534735412464551. PMid:23142798.

30. Barton DL, Liu H, Dakhil S, et al. Wisconsin Ginseng (Panax quinquefolius) to improve cancer-related fatigue: a randomized, double-blind trial, N07C2. J Natl Cancer Inst. 2013;105(16):1230-8. http://dx.doi.org/10.1093/jnci/djt181. PMid:23853057.

31. Su CX, Wang L, Grant S, Liu J. Chinese herbal medicine for cancer-related fatigue: a systematic review of randomizes clinical trials. Complement Ther Med. 2014;22(3):567-79. http://dx.doi.org/10.1016/j.ctim.2014.04.007. PMid:24906595. 